\title{
The origins of integrated models of climate change
}

\section{Élodie Vieille Blanchard}

Centre Alexandre Koyré 27, rue Damesme, 4e étage 75013 Paris, France

Email: elodvb@hotmail.com

\begin{abstract}
The Club of Rome's report The Limits to Growth, published in 1972, asserted the necessity to stop economic and demographic growth in order to avoid the collapse of the world system. It summarised several heterogeneous approaches of the future, somewhere between an ecologically alarmist approach and a typically managerial approach of technological forecasting. The report caused a storm in political and academic circles, but it also led to the development of several modelling methods that in turn framed the issue in a new way, swapping a 'for or against growth' type of approach for a 'what type of growth may be desirable' approach or a 'how to rethink growth to keep it going' approach. Among those, the cost-benefit approach of pollution would turn out to be a significant tool to understand climate change.
\end{abstract}

Keywords: future; environment; limits to growth; mathematical modelling; sustainable development.

Reference to this paper should be made as follows: Vieille Blanchard, É. (2012) 'The origins of integrated models of climate change', Atoms for Peace: An International Journal, Vol. 3, No. 3, pp.238-255.

Biographical notes: Élodie Vieille Blanchard graduated in Mathematics and defended her PhD in History of Science in 2011, about 'The Limits to Growth in a global world'. She is connected with the Centre Alexandre Koyré (EHESS - School of Advanced Social Studies) in Paris.

\section{Introduction}

The year 1972 often appears in treaties on ecology and modelling as the release date of the report to the Club of Rome, The Limits to Growth (Meadows et al., 1972), whose impact in the academic and political world was phenomenal. Although used as a methodological and ideological foil by subsequent work, which grasped environmental questions in the more traditional frame of economic science, the report nonetheless played a major role in establishing a conceptual framework that permitted the treatment of 'global' problems within the framework of mathematical models and in refocusing intellectual issues around environment and development. It thereby contributed to shape the concept of sustainable development.

The intention of this paper is to analyse the precise role of this report in triggering a debate on the future of the world, which in turn led to a fairly strong consensus on the merit of economic growth and in the long run, to legitimising a certain type of modelling of world climate issues that have become central today. To make our point, we shall first dwell on the context in which the report happened: one of questioning the issue of 
'development model' (in the fields of demography, of economy, of the environment and of technology). Then, we shall ponder on how the debate generated by the report fuelled an already latent controversy by involving major scientific and political participants. Finally, we shall move towards how the questions raised by the report generated new models and new discourses which together spurred the development of a new environmental paradigm.

\section{1945-1970, approaches to the future in the USA and in Europe: somewhere in between ecological catastrophism, a normative prospective approach and technological utopianism}

Between 1945 and the end of the 1960s - the period during which the Club of Rome gathered -, understanding the future in its multiple dimensions, on a global geographic scale, translated into various preoccupations and happened in heterogeneous places. There was an increase of discourse about the future and how to tackle it.

Those various approaches focused on two diametrically opposed categories: on the one hand, a 'catastrophist' approach that revolved around the forecast of several major hazards (atomic hazard, world demographic growth, the depletion of natural resources and the explosion of pollutions), something which developed along the lines of various mobilisations and the emergence of various criticisms. On the other hand, a more 'professional' approach emerged as from the end of World War II, with its emblematic figures, its institutional venues and its formalised procedures. It flourished around military issues and considerably widened its scope of study during the 1960s.

\subsection{The making of a catastrophic approach of the future}

The catastrophist approach of the future emerged mainly in the USA after World War II and denounced technological and political transformations linked to the industrialisation of the world and to the process of development. To begin with, several themes emerged from socially minor groups. Then, those themes aggregated and contributed to shaping fairly significant discourses on 'global crisis'.

The theme of atomic hazard emerged first. According to several analysts (e.g. Worster, 1977; Le Bras, 1994), it was at the very root of the development of the ecological thought. The implementation of the atomic bomb symbolised for participants of the atomic project as well as for the general public new access to unprecedented means of destruction. Indeed, following Hiroshima and Nagasaki bombings, newspapers from all political sides (Boyer, 1998) immediately considered plausible the total annihilation of mankind.

In the following months, the very first movement of critical scientists gathered, mainly composed of physicists involved in the Manhattan project. First local associations were set up, and then in January 1946 (Wang, 1999) the movement became a national coordination. The future had pride of place in discourses which revolved around atomic weapons and how they overturned the rules of war and thereby could possibly lead various nations down the path of an eventual annihilation of mankind (Masters and Way, 1946).

This movement declined as from the late 1940s, weakened as it was by repeat government investigations in the context of the Cold War (Wang, 1999). It was born again in the late 1950s when nuclear tests in the Pacific led to serious consequences for local populations. The 'Committee for Nuclear Information', founded by Barry Commoner, 
rallied against those tests. It was no longer a matter of focusing on the spectre of a distant annihilation of mankind, but of relying on precise medical and biological studies to point out the effects of nuclear tests on populations (Egan, 2007). This rallying gathered pace among US public opinion and played a part in the adoption of the Test Ban Treaty in August 1963, which forbade nuclear test in the atmosphere.

The dual theme of population and resources was chronologically the second one to be pervaded by the prospect of a threatening future. In the 1940s, the professionalisation of demography, along with the creation of special structures within the UN, contributed to the production of demographic databases which in turn sparked the interest of nonWestern populations and shed light on their so far little known situations (Chasteland, 2006).

The alarm was first raised about the seriousness of demographic trends and its relation to food resources by 'nature professionals' in the late 1940s. They equated the threat of 'excess population' with that of atomic war and called for birth control. Julian Huxley (first UNESCO director), Fairfield Osborn and William Vogt (ecologists) (Osborn, 1948; Vogt, 1948) were then contradicted by UN agency representatives who believed in the promises of the Green Revolution to feed the world population whatever its growth (Symonds and Carder, 1973).

Demographers, who originally claimed that economic development must lead to a lower birth rate, gradually turned 'pro family planning' and were supported by industrial giants (Ford, Rockefeller). Within the UN, the lobbying by representatives of the 'population movement', along with the ever more numerous censuses and the evolution of demographic forecasting methods, led to the implementation of the first programmes of assisted birth control around 1965 (Symonds and Carder (1973).

Those programmes were vigorously supported by the US administration whilst discourses on the hazards of demographic growth were reclaimed by a booming ecological movement, one that considered demographic growth as threatening, not only for developing countries but also globally. Such an approach, that views demography through the prism of ecology, became dominant among US scientific and political circles (Commission on Population Growth and the American Future, 1972).

The third theme to shape the alarmist discourse on the future was that of pollution. It grew from an important material change in US economy after World War II, namely the industrialisation of agriculture, with its heavy reliance on new chemical products derived from military research (such as DDT) and the industrial 'technological revolution' resorting heavily on new processes and new material.

In 1962, Silent Spring, by biologist Rachel Carson, precisely documented US experiments in spraying insecticide. Her work presented environmental contamination by chemical products as the main problem of the time' along with 'the possible extinction of mankind by nuclear war' (Carson, 1962). The book made an impact in the industrial world, in the general public and in the political administration, the latter passing thereafter several environmental regulating laws.

Throughout the following era, there was mounting criticism of 'affluent' society and of technological progress mainly at first from the middle class or 'leisure' society, but also from some representatives in the Democrat party or from politically more radical leading figures. Burgeoning associations everywhere echoed environmental discourses.

A 'new environmentalism', of a more politicised nature, was being constructed and it focused on the impact that the destruction of the environment had for mankind rather than for nature. 
By the end of the 1960s, birth control had become a consensual subject both in the USA and within the UN and a new discourse - referred to as 'prophetic' by its opponents - forecast a catastrophic future for mankind unless radical change was initiated.

This discourse originated in several works written between 1966 and 1972 that drew much attention and whose authors often made speeches on campuses and in the media (the most well-known are Ehrlich, 1968; Commoner, 1971). Those works documented various themes such as demographic growth, the damaging effect of intensive farming on ecosystems, pollution and the depletion of resources. A sense of emergency and imminent catastrophe pervaded those books, which all relied on a systemic approach characterised by the frequent invocation of the complexity of ecosystems. They also put forward limits to human development and called for a total rethinking of economic and social systems in order to achieve stability.

At the same time, several representatives of a 'heterodox' school in economics, who supported the ecologist school of thought, offered a representation of the economic process based on the principles of thermodynamics. Their representation tackled the question of temporality and irreversibility and focused on the prospect of a threatening future or even a lack of future for mankind (Boulding, 1966; Daly, 1971; Georgescu-Roegen, 1971).

The late 1960 s bore witness to the rise of a socially significant movement, with the birth of many environmental associations and the strengthening of existing ones. This movement peaked in April 1970 with the first 'Earth Day' in which 20 million people took part. Its ideology played a part in the Stockholm conference, whose preliminary report postulated the limits of the environment and the possibility that wild economic growth may lead to 'the end of any life' (Ward and Dubos, 1972, p.102).

\subsection{The development of a professional futurology}

During the same period, a new professional field was born, namely 'future studies'. It first grew around technological questions in the USA whilst taking on a more philosophical and normative form in Europe but before long each view influenced the other.

In the USA, 'technological forecasting' started as from the end of World War II notably with the founding of the RAND Corporation, whose first mission was to analyse and compare alternative choices in defence policy and which gradually broadened its scope to carry out investigations on the future. Soon, military 'technological forecasting' was used by the industry to feed economic planning. The methods used were precisely formalised and in keeping with military approaches (linear programming, graphs, game theory, etc.). They either extrapolated technological approaches or helped solve certain problems in the context of implementing industrial projects (Jantsch, 1967).

In Europe, the future was first theorised in France, in a context of reconstruction - as opposed to that of fresh mobilisation of the USA. Indeed, in the context of post-war national planning, the short-term investigation of the future often led to a more long-term (or 'prospective') approach (Cazes, 2008). Gaston Berger and Bertrand de Jouvenel helped structure this approach. They believed in tackling the future by looking for meaningful ends (a normative dimension that barely existed in the USA) and by envisioning a multitude of possible futures (Jouvenel's 'Futuribles') in order to make choices, rather than consider the future as a mere by-product of technological progress.

From the mid-1960s, the future was tackled in the wake of this legacy: technology no longer occupied a central place and a scientific means of approach was not as important as it was in the USA. Those approaches first came from individuals, before a social network was set up, stimulated by the Mankind 2000 Conference which took place in Oslo in 1967. 
Those approaches criticised US dominance in all things technological and the general lack of interest for social and political issues. They evinced a real interest in international political issues, in democratic participation and in cultural evolution. They cast a rather ambivalent eye on technology (considered as much as a threat as a promise), showed important reflexivity (with repeat questioning on the use of futurology for society) and a strong normative dimension. The idea was to question the goals that society must pursue, rather than project possible or probable futures (Moll, 1991).

While European approaches criticised the deterministic US model centred on technology, US technological forecasting increasingly included social issues. The phrase 'social technology' was coined and technological questions were examined within the framework of urban planning, transport, natural resources or the management of public issues. For instance, the Hudson Institute, founded by Herman Kahn in 1961, specialised in thinking up scenarios on the future in vast military, economic, social and political contexts. It worked mainly for the US government and supplied plenty of data for the year 2000 committee (Jantsch, 1967).

By the late 1960s, two diametrically opposed large-scale research projects were launched on either side of the Atlantic to tackle the year 2000 committee. In the USA, the 'Commission for the Year 2000' was created by the American Academy of Arts and Sciences in order to study the consequences of the industrial economy turning service economy. It commissioned, for that purpose, the Hudson Institute, which did most of the work and whose report bore witness to a particularly confident view of the future. Its main argument was the advent of a 'post-industrial' age, which would lead to the emancipation of humans from their natural basis. Society would move towards a leisure society, in which work would only play a minor part; medicine would evolve and enable doctors to overcome the limits of the human body; man would possibly control climate, produce energy without depleting resources or polluting. This bright future was heralded as the natural destiny of human societies, one that would arrive naturally, without the need to implement certain measures (Kahn and Wiener, 1967).

On the European side, the Mankind 2000 Conference aimed at implementing the methods that were set up in the USA in a military context and applying them to a civilian context. Its report testified to an opening to social and political issues, but also to a certain prescriptiveness (one part was devoted to the 'human aims and implications') and reflexivity. It denounced the ownership of resources by rich countries at the expense of poor countries and put forward a necessary transition towards a stable society for rich countries (on a moral rather than ecological basis) (Jungk and Galtung, 1969).

\section{The scientific impact of the report to the Club of Rome}

In the early 1970s, two reports, World Dynamics and The Limits to Growth presented an already much commented (by promoters of family planning and ecologists) dichotomy. They used global mathematical models (see Box 1) to oppose growth (of population and production) to limited (mineral and agricultural) resources. These reports were drafted for the benefit of a young organisation made up of futurologists and businessmen and named the Club of Rome. The organisation wished to have an efficient communication tool for the issues it tackled. The latter were formalised within the Club as the 'Problematic': an intricate network of global issues that increasingly threatened the future of mankind. 
At first, the Problematic did not appear as a unified notion within the Club: while futurologists Hasan Ozbekhan and Erich Jantsch - who dealt with methodological questions - saw it mainly as an ecological imbalance of the world's system and therefore called for a stabilisation of this system (Ozbekhan, 1969; Ozbekhan, 1970), Aurelio Peccei - founder of the organisation - was more preoccupied by the widening 'technological gap' between the USA and Europe, which needed to be filled by yet more industrial development (Peccei, 1969).

The modelling project settled the question of these two distinct approaches of growth (stabilisation of the system versus rapid growth of certain regions). Besides, it contributed to drastically reducing the number of problems to enter the Problematic. Such topics as hunger and malnutrition, poverty, inadequate political institutions or the arms race, which were part of the initial project (Ozbekhan, 1970), were dropped in favour of purely material aspects (the production of food, the depletion of resources and pollution).

Box 1 What is a global mathematical model?

In the 1970s, several approaches claimed to be able to deal with global problems by using mathematical models. The first models were World 2 and World 3, created for the Club of Rome. They opened the debate on growth. Other models, which relied on varying questionings (linked to energy, to food production or to the development of Southern countries ...) and varying methodologies, contributed to the debate, too. Each model possessed:

1 A structure indicating which variables (or set of variables) were being studied and what were the main relations between them. Sometimes, the structure was represented schematically, as in the World models and its retroactive loops (see Figure 1).

2 Equations that detail more precisely the relationship between variables.

Each of these models relied on a particular modus operandi. Two main categories could be distinguished:

- 'Exploratory' models such as those of the Club of Rome examined the effect of certain initial hypotheses or 'scenarios' that corresponded to forecast evolutions in the future. When the model 'used' these hypotheses or scenarios, it yielded quantified results on the evolution of variables. Exploratory models enabled to answer 'what if...?' questions.

- Optimisation models, such as that of the Bariloche foundation or that of the economist William Nordhaus, sought to establish the 'best value' for a given variable (a carbon tax for instance) or the 'best way' to meet a certain objective (maximising life expectancy for a given period for the Bariloche Foundation, maximising economic growth for Nordhaus). They made it possible to answer questions such as 'what are the best choices in order to ...?'

\subsection{World 1 and World 2: the problematic reconfigured by the Systems Dynamics}

The modelling of the Club of Rome's Problematic was first thought up by Jay Forrester from the Massachusetts Institute of Technology (MIT). He was a dignitary of the military-industrial complex and the author of a modelling methodology: Systems Dynamics. This methodology was devised for industrial purposes. It represented systems as groups of elements related to feedback loops, the latter constituting the very cause of the system. 
Figure 1 The structure of the World 2 model

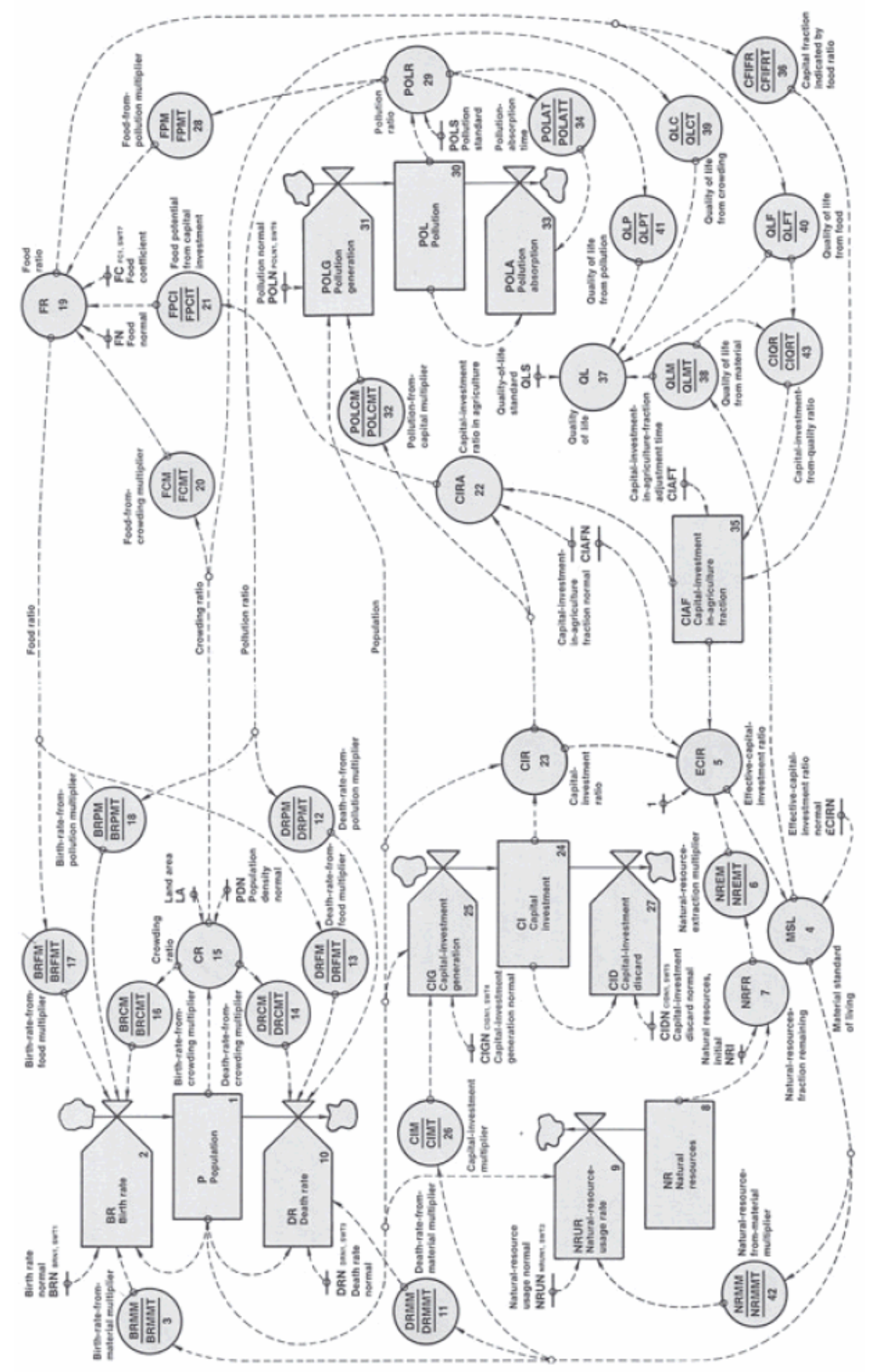


These elements corresponded to variables whose evolution was defined by discreet setting equations interrelating them. This technical arsenal was supported by an exhaustive methodology in Forrester's work. In it, modelling appeared as a means of carrying out virtual experiments on actual systems. Besides, identifying the qualitative behaviour of a system (its growth and then decline, cyclic variations, growth and stabilisation ...) took precedence over a quantified and dated forecast (Forrester, 1961).

The choice of the Systems Dynamics took place in a difficult context for the Club of Rome owing to its financial struggle to fund its modelling project and to scepticism over Osbekhan and Jantsch's proposals, considered too complex by members of the organisation. At the Berne meeting of June 1970, Jay Forrester put forward his methodology and it was adopted a few months later by the Executive Committee of the organisation (Elichirigoity, 1999).

The very first global model of the Problematic - World 2 - was devised by Forrester (1971) alone. It led to the publication of the World Dynamics report in March 1971. The second model - World 3 - was set up from World 2 by a team of young MIT researchers led by Dennis Meadows. It led to the publication of The Limits to Growth in March 1972. The main difference between the different models lay in the number of equations (three times as many in World 3 as in World 2) and in their documentation (the settings were set up almost arbitrarily in World 2 whereas World 3 relied on a certain number of official data). They could also be found in the much more detailed arguments of the second report. However, essentially, the models' structure and the reports' organisation remained the same.

In each of the two models, the main variables were the population, industrial and agricultural capitals, pollution and resources. Each of these variables was supposed to be related to the state of the whole planet. Birth and death rates were calculated from the amount of food available, from pollution, but also from material standards of living and from the population. They were all supposed to be strongly related to material standards of living. More precisely, when the standard of living decreased, mortality was supposed to increase dramatically. Production (or 'industrial capital') was supposed to keep up while relying on natural resources (the latter being apprehended as a finite stock).

The upshot of this structure was that in the basic simulation, World 2 and World 3 both evinced an overshoot and collapse pattern originating from the depletion of resources. This collapse appeared as particularly telling curves that played an important role in the publicising of the results (see Figure 2). Each of these two reports examined the consequences of 'technological' hypotheses supposed to push back the initial limits to growth. These hypotheses led to the modification of a setting, namely the doubling of the stock of initial natural resources. They also enabled to avoid a collapse of the system arising from the depletion of resources, but they resulted in another type of decline, one owing to the sudden increase of pollution.

In World Dynamics, the 'most optimistic' technological hypotheses - that supposed an increase in natural resources and a strong decrease of pollution per production unit led to a growth in the system, followed by a stabilisation phase with a high rate of population. This very scenario was rejected by Forrester precisely because the population was stabilised too high and the standard of living was too low. By contrast, in The Limits to Growth, such hypotheses did not modify the system's behaviour but only pushed back the collapse to a further date.

The authors of both reports therefore examined the consequences of a new, more drastic hypothesis on the model's evolution. The hypothesis was that of a voluntary stabilisation of both population and industrial production. In World Dynamics, Forrester 
examined the consequences of an additional hypothesis: that of a voluntary decrease of global food production. However, this was not taken up in The Limits to Growth. With these two hypotheses, the global system would grow and then quickly stabilise. ${ }^{1}$ The latter scenario was more valued by the report's authors for they advocated structural political breaks in order to move towards stability.

Figure 2 The 'overshoot and collapse' behaviour of World 2 in the basic simulation

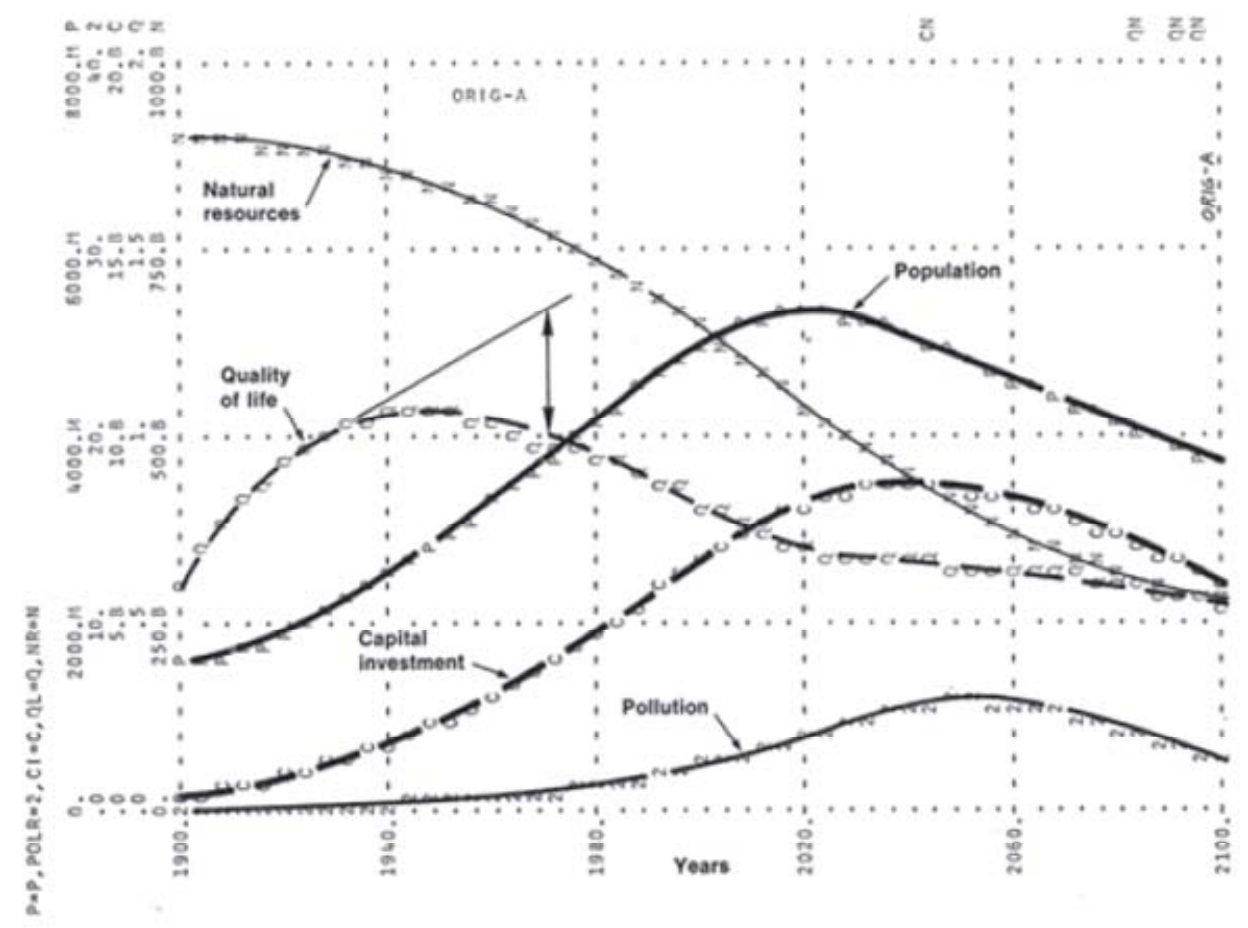

\subsection{The intellectual impact of the Limits report}

While the release of World Dynamics elicited critical reactions in the scientific press, The Limits to Growth raised a storm of intellectual and political protest. Peccei's publicity for the MIT's work played an important part in this reaction. Indeed, a number of scientific and political dignitaries received regular updates of the ongoing work; also the release of the book was accompanied by an important ceremony covered by prominent newspapers on the East coast of the USA (Moll, 1991).

In the Anglo-Saxon world, the recommendation to stabilise world population barely elicited a reaction. However, a zero growth policy - so far only supported by the radical fringe of the ecological movement - was now advocated by elite groups from business and planning backgrounds and was associated with a mathematical modelling of the policy, which elicited sharp reactions from dignitaries who had so far granted little credit to such discourse.

In the months following the release of the report, criticism rained down, mainly from economists and political scientists. The criticism mainly focused on the very structure of the models. ${ }^{2}$ It denounced first and foremost the lack of modelling for economic 
processes and notably for price mechanisms [the latter being meant to stimulate a search for substitutes when certain resources were depleted (e.g. Nordhaus, 1973a)]. It also criticised the 'technological pessimism' that emanated from the reports: on the one hand, technological progress did not appear explicitly in the models and on the other hand, when it was actually taken into account by some scenarios, it was only as linear technological progress - certain constants, such as the amount of available resources, were increased, but their fixity was maintained - whereas those scenarios forecast an exponential growth of population and production.

Several of these critics adopted World 2 in order to integrate those hypotheses that they deemed credible. William Nordhaus (an economist from the Cowles Commission) and Robert Boyd (a zoologist engineer at the University of California) separately assumed that production could do without natural resources beyond a certain level of technological development - this corresponded to the hypothesis of nuclear fusion increasingly enabling to extract and recycle resources as much as necessary - and that it was possible to completely eliminate pollution. With these hypotheses, the system could grow indefinitely (Boyd 1972; Nordhaus, 1973a). For their part, Hugh Cole and Raymond Curnow from the University of Sussex modified the relationship between standard of living and mortality in the model. They also concluded that it was possible to avoid a collapse of the system (Cole and Curnow, 1974).

A second category of criticism consisted of pointing out the strictly technocratic stance of model designers who claimed to direct the whole world on the pretext that they represented the elite (Simmons, 1974). Models aggregation was also criticised for erasing economic domination mechanisms as well as inequalities of wealth between all countries in the world (Ul Haq, 1972; Galtung, 1973). Finally, resorting to modelling was considered as a screen to hide at once assumptions on the world of work - only rich countries' problems are worth studying - and the eminently political aspect of the resulting recommendations.

\subsection{The political impact of the report}

In the political world, only the report's conclusions were discussed, the approach that led to them being barely examined. Within the US government, UN Agencies or European institutions, the report to the Club of Rome was both championed - by defenders of politically radical breaks - and vehemently disparaged - by defenders of the validity of economic growth at the national and international level.

Studies were commissioned by both British and US governments about the report on the Limits and they concluded that recommending the stabilisation of global economy was not justified. However, it was within European institutions that the conclusion of the report was the most hotly debated. The conclusion was taken up by Dutch Commissioner Sicco Mansholt, in the letter he wrote in February 1972 to the President of the European Commission.

In the letter, which anticipated the publication of the report on the Limits, Mansholt used its broad outlines to advocate precise political measures, among which the stabilisation of the world population, priority to food production, a strong reduction in the consumption of material goods per inhabitant, the prolongation of the life expectancy of all equipment goods, the struggle against pollution and the depletion of raw material. He advocated replacing gross national product by 'gross national use' in an economy that would be planned at European level and would favour public investment and restore ecological balance (Mansholt, 1972). 
In France, during the March referendum on the integration of four new countries into the European Community, the Communists, who opposed the project, got hold of Mansholt's letter. Georges Marchais, amongst others, criticised the existence of a plan at 'the highest level of the Common market' aiming at deliberately 'setting back wellbeing. ${ }^{3}$ This 'Mansholt doctrine' as it was presented by the PCF (French Communist Party) was opposed by right-wing and left-wing parties alike, who felt that they had to take position at the beginning of April.

While Georges Marchais condemned the way that Brussels technocrats claimed to secretly organise a planned impoverishment of the population, Paul Huvelin, President of the CNPF (Employers' Association) put forward a necessarily strong economic growth in order to 'improve the standard of living of the poorest'. As for Raymond Barre, he took up the arguments of technological enthusiasts to disprove the need of zero growth. Valéry Giscard d'Estaing for his part considered that the pursuit of growth, not the redistribution of wealth, must solve the problem of poverty (for all of these positions, see Reichenbach and Urfer, 1974).

\section{The building of a consensus around 'another growth': modelling and argumenting}

In the years that followed the publication of the report to the Club of Rome, numerous voices could be heard in favour of a possible compatibility between economic growth and protecting the environment. The new concept of alternative growth - focusing on quality rather than on quantity and minimising the negative effects of growth - was being drawn up. This concept was supported by several modelling enterprises, which moved away from the initial question (growth or stability?) towards a question related to the model of growth (which growth model is advisable?). Despite an actual break from pernicious economic and social processes, this new concept infused political and economic discourses and sent discourses in favour of zero growth or negative growth back to the fringe.

\subsection{The emergence of the concept of sustainable growth}

In the months that followed the publication of the report to the Club of Rome, political circles retaliated with the concept of a new growth, supposed to take into account the dangers mentioned in the report without breaking radically from the previous framework. Such a prospect permeated the conference organised by the European Commission in Venice in April 1972. Manufacturers, union representatives and experts who took part in the conference all insisted on the necessity to break from a growth focused on quantity and to hanker after a development geared towards quality of life, one that would respect the environment whilst developing scientific and technological innovation, one that would 'meet the deepest aspirations of men' (Commission of European Communities, 1972).

In June, at the Stockholm Conference, a group of young scientists from developing countries published a statement claiming that they rejected "certain models of stagnation put forward by some Western ecologists, economists, manufacturers and I.T enthusiasts". They condemned the very rejection of economic growth and accused the capitalist profit system of degrading the environment. They advocated another, more egalitarian global development model (Reported by Galtung, 1972, p.105). 
Two years later, US President Gerald Ford stated in an address to Congress the possible coexistence of the conservation of resources, the preservation of the environment and the increased energy consumption. "The environmental movement has matured", he declared (Ford, 1974). Even though some critics accused him of making such a stand whilst at the same time weakening environmental regulation, such claims comforted public opinion.

These discourses drew on several economists' theories of growth rehabilitation. In 1973, Norhaus and Tobin came up with a new indicator of 'economic well-being' from which 'unfortunate'spending (on defence, police, justice, etc.) might be deducted, while leisure and household activities would be taken into account (Nordhaus and Tobin, 1973). A year later, British economist Wilfred Beckerman wrote a book - In Defence of Economic Growth - in which he agreed with the absurdity of the pursuit of growth for its own sake and attested to its negative effects and in which he demonstrated how a fair growth, one that would justly divide resources among the population throughout the ages, would constitute a very desirable political goal (Beckerman, 1974).

\subsection{The dissolution of the stability versus growth controversy in favour of global modelling and environmental economics}

In the mid-1970s, zero economic growth was rather unpopular within scientific and political communities. In November 1975, a conference aiming at studying more in depth the areas of study of the 1972 report - a conference financed by manufacturer Mitchell and coorganised by the Club of Rome and the University of Houston - did not come up with any pertinent development on the subject. The conference was supposed to gather four times, however, the 1977 conference was not relayed either in the New York Times or in Science (which only published an advertisement) and subsequent conferences, if they took place, did not receive any media coverage.

At the same time, a controversy arose concerning the policy of developed countries on the global production of food and on the stance they should adopt on the matter. Forrester made a name for himself by advocating a 'triage' policy. For him, rich countries should only bring food to those developing countries which agree to implement a drastic family planning policy and should plainly refuse to support countries that do not.

Except for this radical position, the Club of Rome did not remain faithful to the conclusions of the report to the Limits. As from 1972, in response to criticism on the aggregate models of World, they launched a new modelling project led by Mihajlo Mesarovic (from Case Western University, Cleveland) and Eduard Pestel (from Hanover Polytechnic University). In 1974, the report of this work - which relied on an extremely complex modelling methodology (the 'multi-level hierarchical systems theories') applied to a division of the world into ten regions in which the model structure does not appear concluded with the interdependency of the world's regions and the necessity to pursue an 'organic' growth that would be directed at developing the poorest regions in the world, instead of pursuing an 'undifferentiated'growth as had been the case so far (Mesarovic and Pestel, 1974).

In 1976, the RIO (Reshaping the International Order) report, commissioned by the Club of Rome to economist Jan Tinbergen, recommended, in order to bridge the gap between First World and Third World, that rich countries would opt for zero or negative growth in the next 30 years so that developing countries could have a growth rate of 
about 5\% (Tinbergen, 1976). At the time, Peccei considered the report to the Limits as a step enabling to raise certain issues, but he supported the benefits of industrialisation as well as scientific and technological progress.

In the same year, the conclusions drawn from the world model at the Bariloche foundation in Argentina were released in order to respond to the preoccupations of Southern countries. The model was built in order to examine the possibility of achieving precise development projects in various regions of the world. For that purpose, it relied on the optimisation of life expectancy. It concluded that it was possible for Latin America to rapidly reach an acceptable position and that Africa and Asia could follow suit - albeit in the longer run - on condition that investments were managed rationally in those regions. The report also stated that developed countries must accept to stabilise their standard of living in order to enable the poorest to escape poverty (Herrera, 1977).

Mesarovic and Pestel as well as the Bariloche Foundation's models were rooted in the so-called 'global modelling' tradition that developed against the report to the Club of Rome. A dozen models, each focusing on diverse aspects, sprang from this tradition. However, they all dealt with the initial question raised by the report of the Limits, namely that of global development.

Various responses about a possible growth and political priorities arose from these various approaches. Nevertheless, the idea of an interdependent global system and the recommendation to treat problems on a global scale - by relying both on analysis and planning - were common points to all of the reports. Besides, the diverging conclusions from these studies can be explained by their diverse hypotheses and modelling methodologies, positive conclusions about continued growth often resulting from especially optimistic technological hypotheses (Vieille Blanchard, 2010).

This tradition lasted for about ten years in Europe and the USA, as well as in Japan. It involved various participants who had already taken part in the initial project of the Club of Rome and was structured around the International Institute for Applied Analysis - an organisation founded by Peccei in 1972 in the vicinity of Vienna that coordinated and evaluated such diverse research. At the beginning of the 1980s, this tradition lost ground to more sectored modelling, in which smaller geographic entities aggregated.

The 1970s also saw the development of an economic theory of the environment whose first stones were laid before the publication of the report to the Club of Rome, but which was stimulated by the debate surrounding the Limits.

Nordhaus, for one, pursued his own criticism (Nordhaus, 1973a) and came up with a draft on the management of energy resources in a model dating back to 1973. This model relied on the implementation and then generalisation of a technology enabling the production of unlimited energy without depleting resources or polluting. This model might be implemented in 2120 . On this basis, he was hoping to minimise the cost of extracting, transporting and treating resources over a period of 150 years. His model therefore was a model of 'intertemporal optimisation' that relied on hypotheses on the costs of extracting various types of resources from various deposits. It concerned the energy demand of five 'non-communist' regions of the world. Simulations led with this model led, for the period 1970-2120, to a scenario of reliance on oil, gas and coal reserves in order to meet energy demands before turning to over-generation (Nordhaus, 1973b). In the following year, Nordhaus started to broach the subject of climate change: according to him, if one trusted the results of his models, energy supply would not be problematic whereas the impact of burning fossil fuels on the environment should be taken seriously. According to his calculation, the optimal path for the 1970-2120 periods 
- as calculated in his 1973 article - would contribute to increasing $\mathrm{CO}_{2}$ concentration in the atmosphere by $43 \%$ (Nordhaus, 1974). In 1977, he started to study the possibility of 'decarbonising' energy production through a carbon tax. For that purpose, he tweaked his 1973 model, which, though still aiming at minimising energy costs over 150 years, now included a limited use of greenhouse gas emission in order not to double $\mathrm{CO}_{2}$ emission (Nordhaus, 1977).

\subsection{The integrated modelling of climate change}

This work was the first to link energy and greenhouse gas emission and concentration. During the 1980s, such works were still at a preliminary stage. Admittedly, an 'integrated assessment' approach was beginning to emerge to treat environmental problems: experts on the field worked together and exchanged quantitative information, but their work did not rely on formal models that would link diverse disciplinary contributions. At the time, the mathematical models that were implemented in order to link economy and climate only dealt with $\mathrm{CO}_{2}$ and ignored other greenhouse gases. Besides, they did not manage to broach the question of the impact of greenhouse gas on climate and more largely on ecosystems and the economy (Bruce et al., 1996).

It was only around 1990 that integrated assessment modelling began to consider a causal chain ranging from economic and energy policies to emissions and their impact. Nordhaus once more was first to submit an achieved analysis in the field in the form of the DICE model ('Dynamic Integrated Climate-Economy Model'). This model relied on the basic structure of the model developed by Frank Ramsey in the 1920s, whose aim was to optimise, over a period of time, the 'utility' of consumption. Ramsey's model aimed at determining an 'optimal' economic trajectory in which there was arbitration, as from the production stage, between consumption and investment. This optimisation was based on a discounting process, meaning that in the sum of annual uses to maximise, the further in time the year was, the smaller its coefficient. The discounting process therefore consisted in granting more importance to the present and not to the future.

In Nordhaus's model, climate equations were added to this basic structure. In DICE, production depended on the one hand from the population, the technological level and the work, but on the other hand it depended on a 'climate factor'. This factor was calculated for diverse climate policies by combining their costs and benefits. At the beginning of the $1990 \mathrm{~s}$, costs were considered well-known: they had been estimated by 'cost-effectiveness' models that sought to answer such questions as: 'how much will it cost to reduce by a given percentage of greenhouse gas emissions (or concentrations)?' On the other hand, a quantified estimation of the 'benefits' of this policy, that is, of the damages that it enabled to avoid, turned out to be much more complex. To carry out this estimate, Nordhaus relied on works on climatology that he synthesised to extract only some relations or significant settings. Beyond a certain amount of economic activity, his model enabled to calculate corresponding greenhouse gas emissions, which in turn yielded the accumulation of gas in the atmosphere and then the impact of those gases on climate. For the latter link, Nordhaus relied on a small-scale model representing climate as a twolayered system (the atmosphere and superior oceans versus deep oceans). He expressed the cost of the impact on climate as a fractional loss of production (Nordhaus, 1992).

In its 1995 report, the third working group of the IPCC (Intergovernmental Panel on Climate Change), which looked at the socio-economics of climate change, granted special attention to the results of 'integrated assessment' models such as DICE, whose 
results it compiled. These models were for the most part first developed from 1992 and their numbers skyrocketed after that date: three years later, the GIEC identified 22 models 'currently being used or in active development' (Bruce et al., 1996, p.380).

Their common feature was their recommendation to relate fundamental categories (human activities, atmospheric conditions, sea level and climate, and ecosystems) but their structures were fundamentally different. One might identify once more the two main families that were represented in the 'global modelling' debate of the 1970s: on the one hand, optimisation models such as Nordhaus's and on the other hand, evaluation models such as the IMAGE model - itself a direct descendant of the MIT model. The 1970s debate on growth therefore structured the forthcoming theoretical climate postulations of the 1990s on two counts: on the one hand, the debate established the need for mathematical models to link various aspects of human activities and on the other hand, the two patterns that appeared in the debate around growth (exploration/optimisation) eventually met in the integrated approach of climate change.

Thus, if DICE appeared as a more thorough elaboration of Nordhaus's basic work on energy, the IMAGE (Integrated Modelling of Global Environmental Change) model, as developed at the $\mathrm{RIVM}^{4}$ in the Netherlands, operated differently from World models. It was made up of several modules related to one another by retroaction feedbacks, among which: a regionalised model of climate (that enabled to picture climate phenomena much more precisely than DICE), a technological model of global systems, models enabling to take into account the various uses of land and their properties as well as the evolution of agriculture, a socio-economic model enabling to assist simulation through detailed scenarios. This model was both regionalised and precise enough in its phenomenon modelling - contrary to optimisation models that had to oversimplify the actual phenomena that they represented in order to compensate for the optimisation procedure's high demand in computing power. The model also necessitated, just like World models, to be 'fed' by exogenous scenarios on the evolution of the population, economic growth or the high demand in energy, which dramatically restricted its conditions for use (Matarasso, 2003, p.78).

\section{Concluding remarks}

The models developed in the context of the debate around growth and then around the handling of global climate change constituted 'boundary objects' (Star and Griesemer, 1989) in that they enabled various communities (biologists, economists, politicians ...) to get involved in a debate and negotiations that related to many human activities. These models constituted an infrastructure that could represent climatic and economic systems in their interactions, evaluate the effects of alternative policies on climate, determine the 'best' possible choices - with some hypotheses and priorities - and could also confront different views on the workings of climate and economy or the relevance of certain political choices.

In the context of the debate on growth, the first model - which had started a controversy on the validity and possibility of pursuing growth - was fiercely criticised and gave birth to a variety of alternative models. These models highlighted other issues beyond that of the opposition between growth and stability, relied on methodologies other from that of World models and generally concluded with the possibility of economic growth, with some improvements. As for negotiations on climate change, 
several modelling approaches still coexist, but the models will probably be used in the long term. For instance, the DICE model has had a remarkably long fortune since its completion in the 1990s. Several dozen teams have worked on the model and it still regularly occurs in the scientific literature (Matarasso, 2007).

However, despite this remarkable posterity, much debate took place around the parameters and internal choices for the model. Nordhaus's discount rate, for one, was criticised for granting the future too much importance and his hypotheses on the damage of climate change were considered much too optimistic (Sterman and Booth Sweeney, 2002). As a consequence, his 'optimal' trajectory in terms of greenhouse gas emission was close to the 'business as usual' trajectory, in which no effort was made to reduce gas emission.

Such controversies testify to the eminently political character of the modelling enterprise. There is nowadays a rather large consensus to tackle climate issues with the tools of standard economics, which was not the case in the 1970s. However, the criticism and debate that took place on the internal choices of the models shed light on the particular choices of their developers and users. Whole systems of value, indeed political and economical options, come into play when it comes to 'synthesising' complex climatology results or to streamlining them into a few settings. Whole systems are again necessary to grant particular value to a discount rate or even to quantify the damage of climate change, for which exclusively climatic models are not concluding. Precisely what a historical approach of modelling should offer is the need to pay close attention to the way that value systems can influence simulation results, the latter playing a decisive role in shaping political decision.

\section{References}

Beckerman, W. (1974) Defense of Economic Growth, Jonathan Cape, London.

Boulding, K. (1966) 'The economics of the coming spaceship earth', Jarrett, H. (Ed.): Environmental Quality in a Growing Economy, John Hopkins University Press, Baltimore.

Boyd, R. (1972) 'World dynamics: a note', Science, Vol. 177, No. 4048, pp.516-519.

Boyer, P. (1998) Fallout - A Historian Reflects on America's Half-Century Encounter with Nuclear Weapons, Ohio State University Press, Colombus.

Bruce, J.P., Lee, H. and Haites, E.F. (Eds) (1996) Climate Change 1995 - Economic And Social Dimensions of Climate Change - Contribution of Working Group III to the Second Assessment Report of the Intergovernmental Panel on Climate Change, Cambridge University Press, Cambridge.

Carson, R. (1962) Silent Spring, Riverside Press, Cambridge, MA.

Cazes, B. (2008) Histoire des futurs - Les figures de l'avenir de saint Augustin au XXIe siècle, L'Harmattan, Paris.

Chasteland, J-C. (2006) 'La croissance de la population mondiale et la communauté internationale de 1950 à nos jours', Caselli, G., Vallin, J. and Wunsch, G. (Eds): Démographie, analyse et synthèse. VII, Histoire des idées et politiques de population, INED, Paris.

Cole, H. and Curnow, R. (1974) 'Evaluation des modèles du monde', in Cole, H. (Ed.): L'antiMalthus, Seuil, Paris.

Commission des Communautés européennes (1972) Pour un autre modèle de développement, La Librairie Européenne, Bruxelles.

Commission on Population Growth and the American Future (1972) Population and the American future - The Report of the Commission on Population Growth and the American Future. Available online at: http://www.population-security.org/rockefeller/001 population growth and the_american_future.htm 
Commoner, B. (1971) The Closing Circle: Nature, Man, and Technology, Knopf, New York. [French translation: L'encerclement, Paris: Seuil, 1972.]

Daly, H. (1971) 'Toward a stationary-state economy', in Harte, J. and Socolow, R. (Eds): Patient Earth, Holt, Rinehary and Winston, New York.

Egan, M. (2007) Barry Commoner and the Science of Survival - The Remaking of American Environmentalism, The MIT Press, Cambridge, MA.

Ehrlich, P.R. (1968) The Population Bomb, Ballantine Books, New York.

Elichirigoity, F. (1999) Planet Management - Limits To Growth, Computer Simulation, and the Emergence of Global Spaces, Northwestern University Press, Evanston, IL.

Ford, G.F. (1974) Message to the Congress Transmitting Annual Report of the Council of Environmental Quality, 12 December.

Forrester, J.W. (1961) Industrial Dynamics, Cambridge MIT Press, Cambridge.

Forrester, J.W. (1971) World Dynamics, Wright-Allen Press, Cambridge.

Galtung, J. (1973) “"The limits to growth" and class politics', Journal of Peace Research, Nos. 16/17, pp.101-114.

Georgescu-Roegen, N. (1971) The Entropy Law and the Economic Process, Harvard University Press, Cambridge, MA.

Herrera, A.O. (1977) Un monde pour tous, Economie en liberté, PUF, Paris.

Jantsch, E. (1967) La prévision technologique, OCDE, Paris.

Jungk, R. and Galtung, J. (1969) Mankind 2000, Universitetsforlaget, Oslo.

Kahn, H. and Wiener, A.J. (1967) The Year 2000: a Framework for Speculation on the Next Thirty-Three Years, Macmillan, New York.

Le Bras, H. (1994) Les limites de la planète, Flammarion, Paris.

Mansholt, S. (1972) 'Lettre à Franco Maria Malfatti', in Thill, J.C. (Ed.): La Lettre Mansholt Réactions et commentaires, Jean-Jacques Pauvert, Paris.

Masters, D. and Way, K. (Eds) (1946) One World or None, A Report to the Public on the Full Meaning of the Atomic Bomb, McGraw-Hill Book Co., New York.

Matarasso, P. (2003) 'Evaluation intégrée et modélisation - comment le changement climatique a transformé la conception que nous nous faisons des problèmes de décision', Annales des Ponts et Chaussées, Nos. 107/108, pp.73-83.

Matarasso, P. (2007) 'La construction historique des paradigmes de modélisation intégrée: William Nordhaus, Alan Manne et l'apport de la Cowles Commission', in Dahan-Dalmedico, A. (Ed.): Les modèles du futur, La Découverte, Paris.

Meadows, D.H. and Dennis L., Randers, J., Behrens, W.W. III (1972) The Limits to Growth, Universe Books, New York.

Mesarovic, M. and Pestel, E. (1974) Mankind at the Turning Point, Hutchinson, London.

Moll, P. (1991) From Scarcity to Sustainability, Peter Lang, Frankfurt am Main.

Nordhaus, W.D. (1973a) 'World dynamics: measurement without data', The Economic Journal, Vol. 83, No. 322, pp.1156-1183.

Nordhaus, W.D. (1973b) 'The allocation of energy resources', Brookings Papers on Economic Activity, No. 3, pp.529-576.

Nordhaus, W.D. (1974) 'Resources as a constraint on growth', The American Economic Review, Vol. 64, No. 2, pp.22-26.

Nordhaus, W.D. (1977) 'Economic growth and climate, the carbon dioxide problem', The American Economic Review, Vol. 67, No. 1, pp.341-346.

Nordhaus, W.D. (1992) 'An optimal transition path for controlling greenhouse gases', Science, Vol. 58, pp.1315-1319. 
Nordhaus, W.D. and Tobin, J. (1973) 'Is growth obsolete ?', in Moss, M. (Ed.): The Measurement of Economic and Social Performance, Studies in Income and Wealth, Vol. 38, NBER, New York.

Osborn, F. (1948) Our Plundered Planet, Brown and Company, Little, Boston, MA.

Ozbekhan, H. (1969) 'Vers une théorie générale de la planification', in Jantsch, E. (Ed.): Prospective et politique, OCDE, Paris.

Ozbekhan, H. (1970) 'The predicament of mankind - quest for structured responses to growing world-wide complexities and uncertainties', Club de Rome. Available online at: http://quergeist.net/Christakis/predicament.pdf

Peccei, A. (1969) The Chasm Ahead, Macmillan Press, Toronto.

Reichenbach, R. and Urfer, S. (1974) La Croissance zéro, PUF, Paris.

Simmons, H. (1974) 'Dynamique des Systèmes et technocratie', in Cole, H. (Ed.): L'anti-Malthus, Seuil, Paris.

Star, S.L. and Griesemer, J.R. (1989) 'Institutional ecology, "translations" and boundary objects: amateurs and professionals in Berkeley's museum of vertebrate zoology, 1907-39', Social Studies of Science, Vol. 19, No. 4, pp.387-420.

Sterman, J.D. and Booth Sweeney, L. (2002) 'Cloudy skies: assessing public understanding of global warming', System Dynamics Review, Vol. 18, No. 2, pp.207-240.

Symonds, R. and Carder, M. (1973) The United Nations and the Population Question, Chatto \& Windus, London.

Thill, J.C. (Ed.) (1972) La Lettre Mansholt - Réactions et commentaires, Jean-Jacques Pauvert, Paris.

Tinbergen, I. (1976) Reshaping the International Order, E.P. Dutton, New York.

Ul Haq, M. (1972) 'The limits to growth - une critique', Finances et Développement, Vol. 9, No. 4, pp.2-8.

Vieille Blanchard, E. (2010) 'Modelling the future: an overview of the "limits to growth" debate', Centaurus, Vol. 52, pp.91-116.

Vogt, W. (1948) Road to Survival, William Sloane, New York.

Wang, J. (1999) American Science in an Age of Anxiety, The University of North Carolina Press, Chapel Hill.

Ward, B. and Dubos, R. (1972) Only One Earth: the Care and Maintenance of a Small Planet, A. Deutsch, London. [French translation: Nous n'avons qu'une terre. Paris: J'ai lu, 1972.]

Worster, D. (1977) Nature's Economy: a History of Ecological Ideas, Sierra Club Books, San Fransisco, CA.

\section{Notes}

1 Only resources slowly decline, but the authors claim that the slowness of their decline leaves plenty of time to look for substitutes.

2 Mainly that of World 2 in so far as the Limits report did not divulge the list of World 3 equations.

3 Declaration of Georges Marchais at the National Assembly on 4th April 1972 (see Thill, 1972).

4 In Dutch, the acronym stands for (National Dutch Institute for Public Health and Environment. 